口腔内に初発症状を呈した急性骨䯣性白血病の 3 例

\author{
丸川恵理子・吉田文彦・宮崎英隆 \\ 櫻井仁亭·石井良昌·小村 健
}

\title{
Three cases of acute myelogenous leukemia with oral manifestations as initial symptoms
}

\author{
MARUKAWA Eriko · YOSHIDA Yoshihiko · MIYAZAKI Hidetaka \\ SAKURAI Jinkyo · ISHII Yoshimasa · OMURA Ken
}

\begin{abstract}
The initial symptoms of leukemia include oral manifestations such as gingival hemorrhage and swelling. In patients with these symptoms, attention should be paid to the early diagnosis of acute leukemia. This report describes three cases of acute myelogenous leukemia (AML) with initial manifestations in the oral cavity.

Patient 1: A 32-year-old woman. Ulcer lesions of the oral mucosa were diagnosed as decubital ulcers, and symptoms did not respond to the application of steroid ointment. She also had appetite loss, general malaise, and bloody stools. Blood examination showed a low white-cell count $(1,600 / \mu 1)$.

Patient 2: A 52-year-old man. He received anti-inflammatory treatment and had pain at the mandibular third molar region and gingival swelling, but the symptoms did not improve. At the initial visit, pericoronitis of the mandibular third molar with fever and general malaise were observed. Blood examination showed a low white-cell count $(2,300 / \mu 1)$ and remarkably increased myeloblasts $(20 \%)$.

Patient 3: A 54-year-old woman. She received medication to treat full-mouth gingival swelling. However, fever and general malaise persisted. Blood examination showed a high white-cell count $(47,000 / \mu 1)$.

All three patients were given a diagnosis of AML on bone marrow biopsy.

When the patients present with oral symptoms such as gingival swelling and ulcers accompanied by fever and general malaise, blood examinations should be promptly performed for the differential diagnosis of acute leukemia.
\end{abstract}

Key words: acute myelogenous leukemia（急性骨髄性白血病）, initial oral manifestations（初発口腔症状), blood examination（血液検查）

緒言 言

白血病の初発症状として歯肉出血や歯肉腫脹が認められ ることがある.これらの症状を主訴として柬科や口腔外科 を受診した白血病患者を早期に診断することは柬科医にと って重要である.

今回, 口腔病変が初発症状であった急性骨髄性白血病 (AML) の 3 例を経験したので，その口腔内所見，全身所 見および初発症状の出現から確定診断に至るまでの臨床経 過について検討したので報告する.

東京医科柬科大学大学院医柬学総合研究科口腔機能再構築系 口腔機能再建学講座顎口腔外科学分野

(主任：小村 健教授)

Oral and Maxillofacial Surgery, Department of Oral Restitution, Division of Oral Health Sciences, Graduate School Tokyo Medical and Dental University (Chief: Prof. OMURA Ken)

受付日：2009年 2 月 19 日

採択日：2010年 2 月 23 日
症

例

\section{症例 1}

患 者：32 歳, 女性.

初 診：2005 年 7 月中旬.

主 訴：難治性の口内炎.

既往歴：アトピー性皮虞炎, 先天性白内障, 子宮内膜症.

家族歴：祖父と祖母は AML, 父は大腸癌, 母は子宮頸癌 であった。

現病歴：1998 年頃より年に $3 \sim 4$ 回の頻度で口腔内に 潰瘍性病変の出現を認めていた. 2004 年 12 月頃より全身 倦㤐感, 月経過多および血便を認めるようになり, さらに 2005 年 4 月頃からは潰瘍性病変が多発し, 接触痛と嬹下痛 のため椇食が困難となった. また, この頃より $37{ }^{\circ} \mathrm{C}$ 台の発 熱と週 1 ～ 2 回の頻度で血便を認めるようになったため, 某内科を受診したが病因は特定されなかった. 同年 6 月舌 潰瘍を認めたため, 某大学病院蒾科口腔外科を受診, 生検 
により舌の褯創性潰瘍と診断された．同科では㐘の研磨と ステロイド含有軟膏の塗布が指示された. 7 月初旬, 左側 下唇に潰瘍性病変が出現したため, 某耳鼻咽喉科を受診し, 軟膏の投与を受けたが改善せず，当科を紹介され受診した.

現 症:

全身所見；全身倦急感，食欲不振および血便を認めた.

口腔外所見 ; 両側顎下リンパ節は弾性軟, 可動性であっ たが，圧痛を伴い， $1.5 \mathrm{~cm}$ 大に腫大していた。

口腔内所見 ; 右側煩粘膜に $1.2 \mathrm{~cm} \times 0.6 \mathrm{~cm}$ 大，右側軟口 蓋に $0.6 \mathrm{~cm} \times 0.6 \mathrm{~cm}$ 大，左側舌背部に $0.3 \mathrm{~cm} \times 0.3 \mathrm{~cm}$ 大， 左側下唇に $1.8 \mathrm{~cm} \times 0.9 \mathrm{~cm}$ 大の辺縁不整な潰瘍性病変を認 めたが，潰瘍周囲に硬結は触知されなかった（写真 1). 特 に, 煩粘膜と軟口蓋の病変は深く, 接触痛と嚥下痛が著し かった. 舌と下唇の病変の一部には上皮化を認めた.

臨床診断：多発性潰瘍性口内炎.

処置および経過：休養と安静を指示し, 経腸成分栄養剤 液とアミノ安息香酸エチル含有アズレンスルホン酸ナトリ ウム CMC-Na 軟膏を処方した。 また，多発性のアフタには 全身性疾患の関与が疑われ，そのために行った血液検査で 赤血球数は $296 \times 10^{4} / \mu 1$, へモグロビン $10.4 \mathrm{~g} / \mathrm{dl}$ と軽度の 貧血を認め, 白血球数は $1,600 / \mu 1$ と減少し，その分画では リンパ球が $54 \%$ と高值を示していた（表 1). 初診 1 週間 後には潰瘍の縮小を認めたが，この時の血液検査ではさら に骨髄芽球が $34 \%$ と著しく増加し，急性白血病が疑われ たため, 本学血液内科を対診した。この時, 悪寒戦慄を伴 う $39{ }^{\circ} \mathrm{C}$ 発熱を認め, 血液内科に緊急入院した. 入院後, 直ちに行われた骨髄穿刺により AML（M2：急性骨髄芽球 性白血病）と診断された（写真 2). その後, 化学療法が行 われたが，2006年 1 月に原病死した。 なお，口腔内の潰瘍 性病変は化学療法の開始とともに消失し, 食欲不振も改善 した。途中， 56 間部の口蓋粘膜に肉芽腫様の腫瘤を認 め, 徐々に周囲粘膜が壊死し, 拡大傾向を示したために, 生検 を施行したところ壊死組織と䛦断された. 死亡までの間に壊 死組織は自然脱落し, その後脱落した粘膜は正常に治癒した.

\section{症例 2}

患 者： 52 歳, 男性.

初 診：2005 年 8 月中旬.

主 訴 : 左側下顎智㐘部の疼痛, 開口障害および摂食障害.

既往歴：高血圧症，高脂血症.

家族歴：特記事項なし.

現病歴：2005年 7 月上旬, 76 部の柬肉腫脹を認め某菌 科を受診した. 辺縁性柬周炎の診断のもとに柬周治療が行な われ, 㐘肉腫脹は消失した. 同年 8 月上旬より, 8 周囲柬肉 の腫脹と疼痛を認め, 歯科を再受診した. 抗菌薬と鎮痛薬の投 与を受けるも症状は増悪したため, 当科を紹介され受診した.
表1 初診時の血液検査所見

\begin{tabular}{|c|c|c|c|c|}
\hline & & 症例1 & 症例2 & 症例3 \\
\hline 赤血球数 & $\left(\times 10^{4} / \mu 1\right)$ & $296 *$ & $211 *$ & $290 *$ \\
\hline へモグロビン & $(\mathrm{g} / \mathrm{dl})$ & $10.4 *$ & $7.5 *$ & $9.2 *$ \\
\hline ヘマトクリット & $(\%)$ & $29.3 *$ & $21.9 *$ & $29.3 *$ \\
\hline $\mathrm{MCV}$ & (fl) & $99 *$ & $103.8 *$ & $101 *$ \\
\hline $\mathrm{MCH}$ & (pg) & 35.1 & 35.5 & 31.7 \\
\hline $\mathrm{MCHC}$ & $(\%)$ & 35.5 & 34.2 & $31.4 *$ \\
\hline 白血球数 & $\left(\times 10^{2} / \mu 1\right)$ & $1.6 *$ & $2.3 *$ & $47.9 *$ \\
\hline 血小板数 & $\left(\times 10^{4} / \mu 1\right)$ & $12.2 *$ & 18.0 & $12.6 *$ \\
\hline CRP & $(\mathrm{mg} / \mathrm{dl})$ & $0.71 *$ & $2.97 *$ & 0.14 \\
\hline 骨髄芽球 & $(\%)$ & - & $20 *$ & - \\
\hline 前骨髄球 & $(\%)$ & - & $20 *$ & $8 *$ \\
\hline \multicolumn{5}{|l|}{ 好中球 } \\
\hline 骨髄球 & $(\%)$ & - & - & $5 *$ \\
\hline 後骨髄球 & $(\%)$ & - & $1 *$ & - \\
\hline 桿核球 & $(\%)$ & 12 & $0 *$ & 6 \\
\hline 分葉核球 & $(\%)$ & $30 *$ & $1 *$ & $13 *$ \\
\hline 好酸球 & $(\%)$ & 1 & 0 & $0 *$ \\
\hline 好塩基球 & $(\%)$ & 0 & 1 & 0 \\
\hline 単球 & $(\%)$ & 3 & 3 & $54 *$ \\
\hline リンパ球 & $(\%)$ & $54 *$ & $48 *$ & $14 *$ \\
\hline
\end{tabular}

\section{現 症：}

全身所見 ; 体温は $37.5^{\circ} \mathrm{C}$, 全身倦急感ならびに食欲不振 を認めた。

口腔外所見 ; 左側煩部から顎下部に腫脹と圧痛を認め た. 両側の顎下リンパ節は直径 $1.0 \mathrm{~cm}$ で，弾性軟，可動性 で圧痛を伴っていた。

口腔内所見； 8 は半埋伏状態であり, その周囲歯肉から 煩粘膜，ならびに口底に発赤，腫脹および圧痛を認めた. また，開口障害を認め，最大開口量は $1.2 \mathrm{~cm}$ であった.

$\mathrm{X}$ 線所見 ; パノラマ $\mathrm{X}$ 線写真にて $\sqrt{8}$ はやや遠心傾斜し, その遠心部の歯槽骨にX 線透過像を認めた（写真 3).

臨床診断：左側下顎智菌周囲炎および下顎骨周囲炎.

処置および経過：初診時より抗菌薬 CEZ 1.0g/日の点滴 投与を行い，休養と安静を指示した．血液検査では，赤血 球数 $211 \times 10^{4} / \mu 1$, へモグロビン $7.5 \mathrm{~g} / \mathrm{dl}$ と貧血を認め, 白血球数は $2,300 / \mu 1$ と減少し，その分画では骨髄芽球が $20 \%$ 占めていた。 また, CRP は $2.97 \mathrm{mg} / \mathrm{dl}$ と上昇してい た（表 1). 以上の検査所見から急性白血病を疑い, 近在病 院の血液内科に紹介した。そこで骨髄穿刺が行われ，AML （M3：急性前骨髄球性白血病）と診断された. 直ちに入院 の上, 化学療法が行われ, 緩解導入がなされ退院となり, 現在, 生存中である. なお, 化学療法中に $\sqrt{8}$ 周囲炎から緑 膿菌による敗血症を併発したが，ピペラシリンナトリウム とクリンダマイシンの投与, 造血機能の回復により治癒した.

\section{症例 3}

患 者： 54 歳, 女性. 


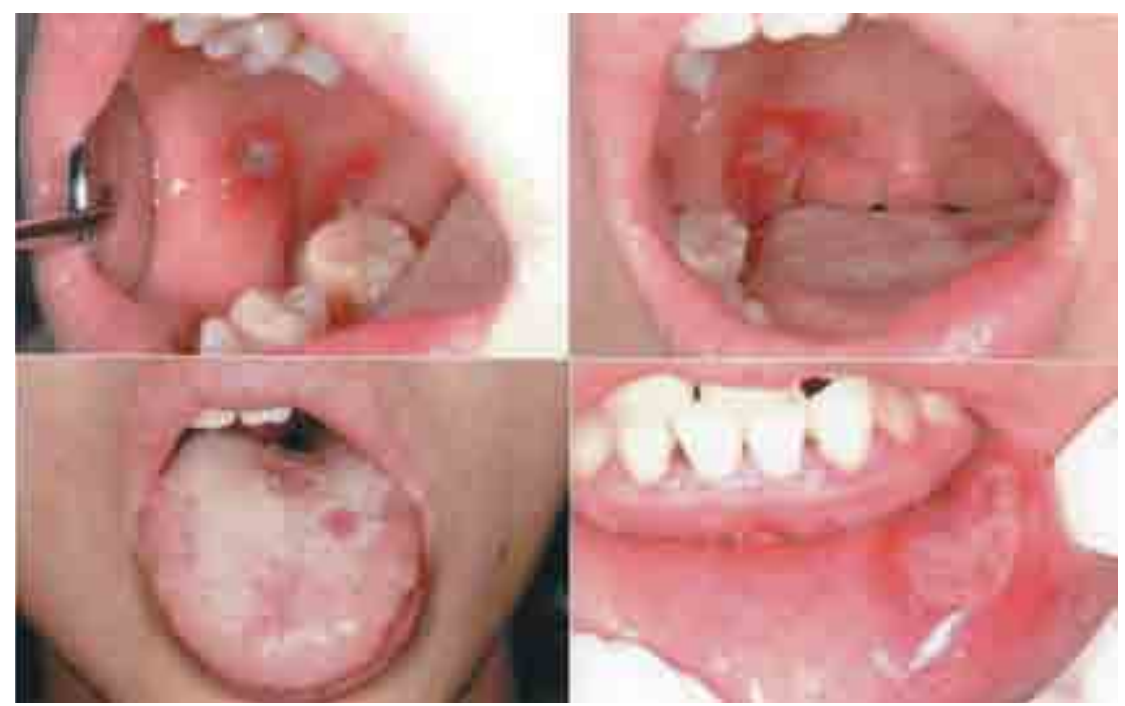

写真 1 症例 1 の初診時口腔内

右側頓粘膜 (左上), 右側軟口蓋 (右上), 左側舌背部 (左下), 左側下唇 (右 下）に潰瘍性病変を認めた.

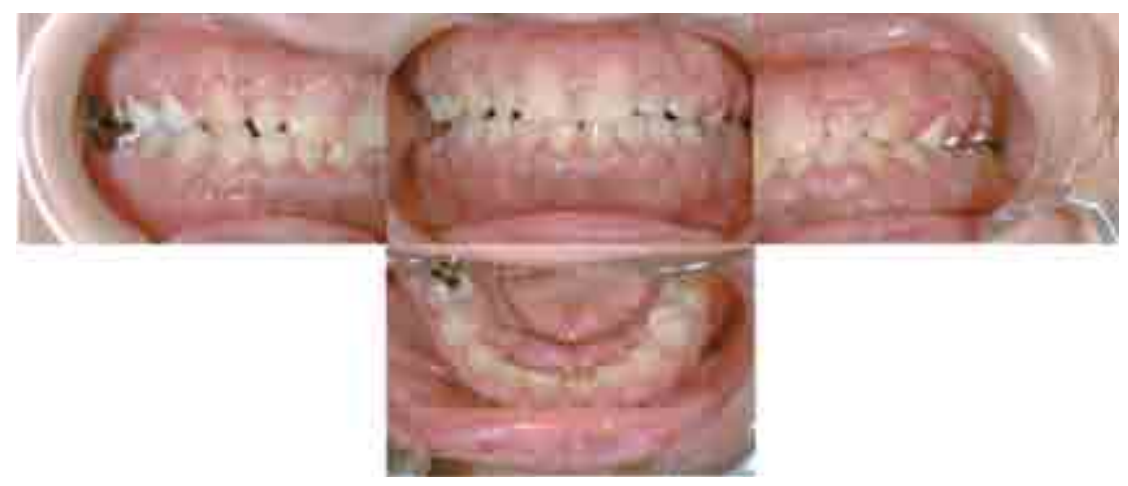

写真 4 症例 3 の初診時口腔内

全顎にわたる歯肉腫脹を認め, 特に下顎舌側㐘肉の腫脹は著明であった.

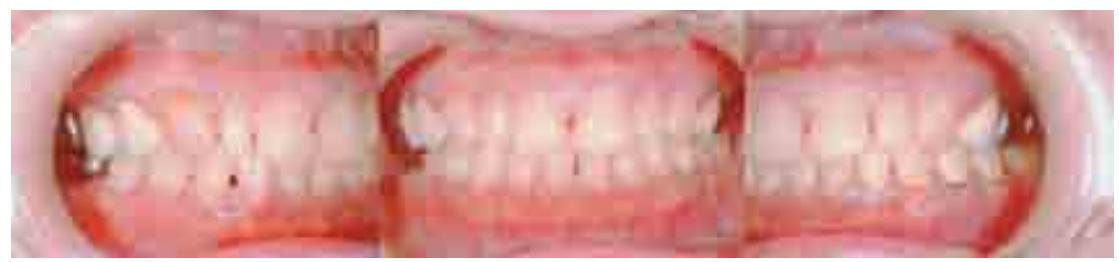

写真 6 症例 3 の化学療法後の口腔内 全顎にわたる茵肉腫脹は改善された.

初 診：2006 年 10 月中旬.

主 訴：上下顎蒾肉の腫脹.

既往歴：子宮筋腫.

家族歴 : 父は肝癌であった。

現病歴：2006 年 9 月中旬, 左側下顎㐘肉の腫脹を自覚 した. その後, 腫脹は下顎歯肉全体から上顎菊肉にも拡大 し，また $39{ }^{\circ} \mathrm{C}$ 台の発熱をきたすようになったため， 9 月下 旬，某内科を受診した。アモキシシリン・クラブラン酸カ

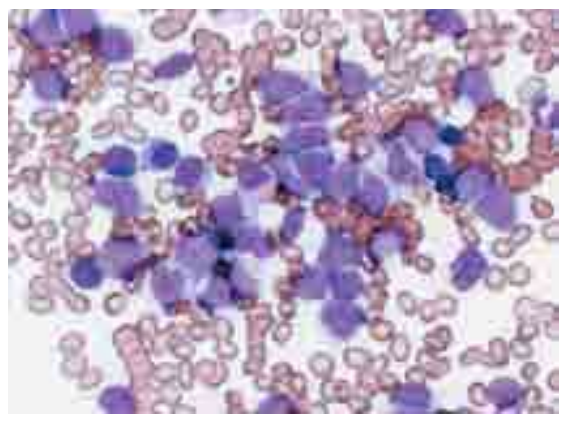

写真 2 症例 1 の骨骾穿刺塗抹標本 （ライトギムザ染色， × 600) 有核細胞の大部分は幼若な骨髄芽 球で占められていた.

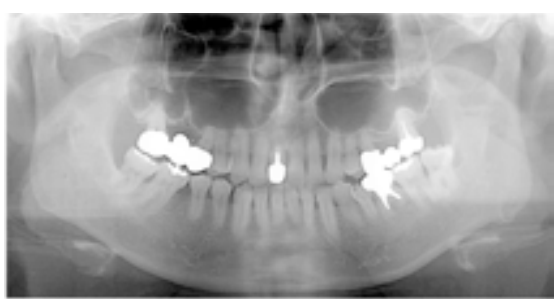

写真 3 症例 2 の初診時パノラマ $\mathrm{X}$ 線像

$\sqrt{8}$ はやや遠心傾斜し, 遠心部茵槽 骨にX 線透過像を認めた.

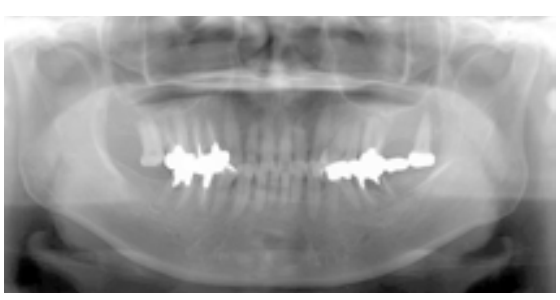

写真 5 症例 3 の初診時パノラマ X 線像

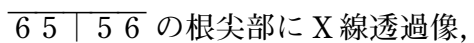
$\sqrt{6}$ に㐘根破折を認めるも，全顎的な 水平性骨吸収は軽度であった。

リウム，ロキソプロフェンナトリウムお よびアズレンスルホン酸ナトリウム含 嗽薬が投与され，㐘肉腫脹はやや軽減し たが，37〜 $38{ }^{\circ} \mathrm{C}$ の発熱が持続するため，10月上旬，某耳 鼻科を受診し，アモキシシリン，ロルシカム，トラネキサ ム酸，レバミピドの投与を受けた。これにより苗肉腫脹は やや軽減したが, $37{ }^{\circ} \mathrm{C}$ 台の発熱は持続し, 全身倦急感を伴 うようになったため，当科を紹介され受診した。

現 症:

全身所見 ; 体温は $36.8{ }^{\circ} \mathrm{C} て ゙$, 全身倦急感および食欲不振 を認めた。 
表2 本邦における口腔内症状を呈したAML症例

\begin{tabular}{|c|c|c|c|c|c|c|c|c|c|c|c|c|c|c|c|c|c|c|c|}
\hline \multirow[b]{2}{*}{ 症例 } & \multirow[b]{2}{*}{ 年齢/性 } & \multirow[b]{2}{*}{ 報告者 } & \multirow[b]{2}{*}{$\begin{array}{l}\text { FAB } \\
\text { 分類 }\end{array}$} & \multicolumn{8}{|c|}{ 口腔内症状 } & \multicolumn{6}{|c|}{ 全身症状 } & \multirow[b]{2}{*}{$\begin{array}{c}\text { 口腔内症状 } \\
\text { 出現 } ら \\
\text { 確 定診 断 } \\
\text { までの期間 } \\
\text { (日) }\end{array}$} & \multirow[b]{2}{*}{ 転帰 } \\
\hline & & & & $\begin{array}{l}\text { 歯 } \\
\text { 肉 } \\
\text { 出 } \\
\text { 血 }\end{array}$ & $\begin{array}{l}\text { 粘 } \\
\text { 膜 } \\
\text { 出 } \\
\text { 血 }\end{array}$ & $\begin{array}{l}\text { 粘 } \\
\text { 膜 } \\
\text { 血 } \\
\text { 腫 }\end{array}$ & $\begin{array}{l}\text { 粘 } \\
\text { 膜 } \\
\text { そ } \\
ら \\
\swarrow\end{array}$ & $\begin{array}{l}\text { 粘 } \\
\text { 膜 } \\
\text { 潰 } \\
\text { 瘍 }\end{array}$ & $\begin{array}{l}\text { 歯 } \\
\text { 肉 } \\
\text { 腫 } \\
\text { 脹 }\end{array}$ & $\begin{array}{l}\text { 腫 } \\
\text { 瘤 } \\
\text { 形 } \\
\text { 成 }\end{array}$ & $\begin{array}{l}\text { 白 } \\
\text { 色 } \\
\text { 変 }\end{array}$ & $\begin{array}{l}\text { 全 } \\
\text { 身 } \\
\text { 倦 } \\
\text { 意 } \\
\text { 感 }\end{array}$ & $\begin{array}{l}\text { 発 } \\
\text { 熱 }\end{array}$ & $\begin{array}{l}\text { 顔 } \\
\text { 面 } \\
\text { 白 }\end{array}$ & $\begin{array}{l}\text { 食 } \\
\text { 欲 } \\
\text { 不 } \\
\text { 振 }\end{array}$ & $\begin{array}{l}\text { 皮 } \\
\text { 出 } \\
\text { 血 }\end{array}$ & $\begin{array}{l}\text { リ } \\
\text { パ } \\
\text { 節 } \\
\text { 腫 } \\
\text { 脹 }\end{array}$ & & \\
\hline 1 & $54 / \mathrm{M}$ & 岡本ら & M2 & 0 & & 0 & & & 0 & & & 0 & $\bigcirc$ & & & & $\bigcirc$ & 5 & 死亡 \\
\hline 2 & $48 / \mathrm{M}$ & 岡本ら & M2 & $\bigcirc$ & 0 & & & & 0 & & & & & $\bigcirc$ & & & $\bigcirc$ & 4 & 生存 \\
\hline 3 & $20 / \mathrm{M}$ & 岡本ら & M2 & & & & 0 & & & & $\bigcirc$ & & & & & & & 30 & 生存 \\
\hline 4 & $59 / \mathrm{M}$ & 岡本ら & M3 & $\bigcirc$ & $\bigcirc$ & $\bigcirc$ & $\bigcirc$ & & 0 & & & $\bigcirc$ & $\bigcirc$ & $\bigcirc$ & $\bigcirc$ & $\bigcirc$ & & 7 & 生存 \\
\hline 5 & $72 / \mathrm{F}$ & 岡本ら & M3 & $\bigcirc$ & & & & & & & & $\bigcirc$ & & $\bigcirc$ & $\bigcirc$ & $\bigcirc$ & $\bigcirc$ & 14 & 生存 \\
\hline 6 & $33 / \mathrm{M}$ & 古土井ら & M1 & & & & & & $\bigcirc$ & & & & $\bigcirc$ & $\bigcirc$ & & & $\bigcirc$ & 37 & 生存 \\
\hline 7 & $46 / \mathrm{M}$ & 吉松ら & M2 & & $\bigcirc$ & & $\bigcirc$ & $\bigcirc$ & & $\bigcirc$ & & & $\bigcirc$ & $\bigcirc$ & & & $\bigcirc$ & 46 & 死亡 \\
\hline 8 & $69 / \mathrm{M}$ & 山田ら & M4 & 0 & 0 & & & 0 & & & $\bigcirc$ & & & & & & & 14 & 死亡 \\
\hline 9 & $53 / \mathrm{M}$ & 小泉ら & M1 & $\bigcirc$ & & & & & & & & $\bigcirc$ & & & & $\bigcirc$ & $\bigcirc$ & 2 & 生存 \\
\hline 10 & $43 / \mathrm{M}$ & 露木ら & M3 & 0 & & & & & 0 & & & 0 & $\bigcirc$ & $\bigcirc$ & & $\bigcirc$ & & 2 & 生存 \\
\hline 11 & $37 / \mathrm{M}$ & 平野ら & 不明 & & & & & & & $\bigcirc$ & & $\bigcirc$ & & & & & $\bigcirc$ & 106 & 死亡 \\
\hline 自験例1 & $32 / \mathrm{F}$ & & $\mathrm{M} 2$ & & & & & 0 & & & & 0 & $\bigcirc$ & & 0 & & $\bigcirc$ & 210 & 死亡 \\
\hline 自験例 2 & $52 / \mathrm{M}$ & & M3 & & & & & & 0 & & & 0 & $\bigcirc$ & & $\bigcirc$ & & & 8 & 生存 \\
\hline 自験例3 & $54 / \mathrm{F}$ & & M4 & & & & & & $\bigcirc$ & & & & $\bigcirc$ & & $\bigcirc$ & & $\bigcirc$ & 26 & 生存 \\
\hline
\end{tabular}

○:症状の存在を示す

FAB分類：M1：急性骨髄芽球性白血病

M2：分化傾向をもつ急性骨髄芽球性白血病

M3：急性前骨髄球性白血病

M4：急性骨髄単球性白血病

ロ腔外所見 ; 右側顎下リンパ節は $1.5 \mathrm{~cm}$ 大で，弾性軟， 可動性, 圧痛を伴っていた.

口腔内所見 ; 全顎にわたる歯肉腫脹を認め, 特に下顎舌 側柬肉に著しい腫脹を認めた (写真 4). 菊石の沈着を認め たが，菊肉は白色調で疼痛やプロービングによる出血は認 めなかった。

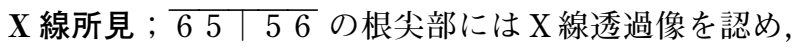
$\sqrt{6}$ に茵根破折を認めるも，重度の茵周疾患を疑わせる水 平性骨吸収は認めなかった（写真 5 ).

臨床診断：白血病による㐘肉腫脹の疑い.

処置および経過：初診時の血液検査で赤血球数 $290 \times$ $10^{4} / \mu 1$, へモグロビン $9.2 \mathrm{~g} / \mathrm{dl}$ と貧血を認め, また, 白血球 数は $47,000 / \mu 1$ と著しく増加し, 前骨髄球が $8 \%$, 骨髄球 が $5 \%$, 単球が $54 \%$ 占めていた（表 1). 口腔内所見と 血液所見から急性白血病を疑い, 本学血液内科に対診した. 血液内科で骨髄穿刺が行われ, AML（M4：急性骨髄単球 性白血病）と診断され，直ちに化学療法が施行された。寛 解導入とともに㐘肉腫脹も消失し, 現在, 生存中である (写真 6).

\section{考察}

白血病の口腔内症状に関して，急性白血病は比較的初期 の段階から, 口腔粘膜の発赤, 腫脹, 柬肉肥大, 出血を, 時 に口腔粘膜の壊死・壊疽を呈すとされている ${ }^{1,2)}$. 一方， 慢性白血病では, 初期に頸部リンパ節腫脹を認めることは
あるものの，末期あるいは急性増悪時などに柬肉出血を認 めることがあるとされている ${ }^{3,4)}$. 慢性白血病は健康診断 等の血液検査により偶然発見されることが多く, 診断が確 定した後に口腔内症状を認め, 㐘科あるいは口腔外科に紹 介されることが多い.つまり, 口腔内症状を初発とする白 血病の多くは急性白血病とみなすことができる.

急性白血病の初期症状としては, 発熱, 出血傾向, 貧血, 全身倦急感ならびに口腔内症状が多く, その中で口腔内症 状は $20 〜 35 \%$ に認められる. また, 中には急性白血病の 65 ～ $80 \%$ に何らかの口腔内症状を認めたとする報告もあ $3^{1,2)}$. 口腔内症状としては歯肉出血や口腔粘膜出血など の口腔内出血が最も多く, その他には歯肉腫脹, 口腔粘膜 潰瘍，口腔感染症などが報告されている ${ }^{1 － 5)}$.

1988 年以後に, 本邦において報告された口腔内に初発症 状を呈した AMLの概要を表 2 に示す ${ }^{5 \sim 10,14)}$. 口腔内症 状としては, 㐘肉出血, 粘膜出血, 歯肉腫脹, 腫瘤形成, 粘 膜潰瘍, 白色病変, 咽頭痛, 蜂窩織炎, 柬痛, 㐘の動摇など が報告されている。この他にも，広範な軟口蓋潰瘍 ${ }^{11 ） p ~}$ 味覚異常 ${ }^{12)}$ の報告がある. また, 全身的な初発症状とし ては, 全身倦急感, 発熱, 貧血 (顔面蒼白), 食欲不振, 出 血傾向，リンパ節腫脹が報告されている.

口腔外科受診時に，出血傾向が認められる場合には血液 内科等に対診され比較的早期に診断が確定することが多い が, 腫瘍, 粘膜疾患あるいは柬周炎が疑われる場合には確 定診断までに長期間を要すことが多い. 表 2 においても, 
柬肉出血を認める症例や出血傾向を呈しやすい M3 症例で は, 確定診断までの時間が短い傾向を示している. 自験の 症例 1 では, 舌潰瘍の生検は施行されていたが血液検査は 施行されず，確定診断までに時間を要した。また，症例 2 のように初発症状が比較的軽度の蒾性感染症を呈す場合に は，血液検查が行われることは少なく診断が遅れる傾向に ある.また全顎的な㐘肉腫脹を呈した症例 3 では，抗菌薬 により症状の改善を認めたこともあり局所的な炎症と診断 され，血液検查が施行されていなかった。このような症例 においても，前述した発熱や全身倦急感などの全身所見を 注意深く観察することが重要と考えられる. 白血病で認め られる口腔内の腫瘤形成や㐘肉腫脹は単球由来の白血病, 特に M4（急性骨髄単球性白血病）で多く認められる.腫 瘤や歯肉腫脹は白血病細胞の浸潤によるものと, 白血病に 伴う出血傾向や口腔衛生状態の悪化などによる炎症性のも のとがある. 前者は腫瘤形成性白血病と呼ばれ, 1898 年 に Eichhorst ${ }^{13)}$ が報告して以来，比較的多く報告されてい る ${ }^{14,15)}$. 症例 3 は M4 であり, 柬石沈着を認めるものの柬 肉出血は認めず, 全顎的な柬肉腫脹は前者によるものと考 えられた．また，白血病で認められる出血傾向は，骨髄内 での白血病細胞増殖による骨髄巨核球細胞の減少がその最 大の原因とされている. 血小板数が 5 万/ $\mu 1$ 以下で, フィ ブリン体分解産物（FDP） が $10 \mu \mathrm{g} / \mathrm{ml}$ 以上の白血病では, $92 \%$ に腔内出血を認めるとされている ${ }^{16)}$. 症例 3 にお いては軽度貧血を認めたが，極度の血小板減少を認めなか ったため, 出血傾向を示さなかったと考えられた.

山田ら ${ }^{8)}$ は口腔内症状を契機に発見された AML 患者の 口腔内症状と転帰との関係について検討し, 潰瘍形成・㐘 の動摇・開口障害では $100 \%$, 口腔外腫脹では $83.3 \%$, 口 腔粘膜の点状出血・玟状出血では $80 \%$, 口腔内腫瘤では 75 \%が死亡したと報告している. また, 口腔内出血と潰瘍を認め る症例では, 1 年生存率が悪いとする報告もある ${ }^{17)}$. 表 2 に 示すように, 自験例を含めた 14 例の AMLのうち, 潰瘍形成 を認めた 3 例, 腫瘤形成を認めた 2 例は全例, 死亡していた.

以上のように, AML を含めて急性白血病の初発症状と しては貧血による症状（全身倦急感，顔面蒼白，動悸，息 切れ), 血小板減少による出血症状 (皮下・粘膜出血斑, 㐘 肉出血, 鼻出血), 正常白血球減少による感染症状 (発熱, 遷延する感冒様症状）が挙げられている.これらの症状は 突然出現することが多いが, 全身倦急感, 微熱, 食欲不振, 頭痛などの前駆症状の後に出現することも多い. そのため, 口腔内出血, 歯肉腫脹, 柬性感染症などの口腔内症状を認 め，かつ前述の全身症状を認める場合には，たとえその症 状が潰瘍性口内炎や智柬周囲炎といった日常的に遭遇する 疾患と同程度であっても白血病を考慮して血液検査を実施 すべきものと考えられた.

\section{結語}

口腔内にその初発症状を認めた急性骨骾性白血病 3 例を 経験したので，確定診断に至るまでの概要を報告した．

口腔外科あるいは柬科を受診する患者のなかで, 全身的 症状を有する場合は血液検査等の全身検索をおこなうべき である。

本論文の要旨は, 第 52 回日本口腔外科学会総会（2007 年 9 月, 名古屋市) に捣いて発表した。

\section{引用 文 献}

1）高木 実, 石川梧朗：白血病の口腔所見について. 口 病誌 49: 524-534 1982.

2) Josephine, W.U., John, E.F., et al.: Oral manifestations of acute myelomonocytic leukemia: a case report and review of the classification of leukemias. J Periodontol 73: 664-668 2002.

3) McKenna, S.J.: Leukemia. Oral Surg Oral Med Oral Pathol Oral Radiol Endod 89: 137-139 2000.

4）石川梧朗 監修: 口腔病理学 II. 永末書店, 京都, 1995, 190-194 頁.

5）岡本圭一郎, 和田 健, 他：口腔症状を契機に発見さ れた白血病症例の臨床的観察. 口科誌 47: 108-114 1998.

6）古土井春吾, 吉位 尚, 他: 下顎柬肉腫瘤を初発症状 とした急性骨髄性白血病の 1 例. 日口診誌 12: 4985031999.

7）吉松俊明, 中村芳明, 他: 舌の腫瘤形成を初発症状と した急性骨髄性白血病の 1 例. 癌の臨床 46: 378-382 2000.

8）山田美穂子, 乾 真登可, 他：上顎㐘肉腫脹を初発症 状とした急性骨䯣性白血病の 1 例. 日口診誌 13: 4394422000

9）小泉敏之, 鳥塚佳代子, 他：スケーリング後の柬肉出 血を契機に発見された急性骨髄性白血病の 1 例. 有 病者菌科医療 15: 25-28 2006.

10）露木基勝, 今井裕一郎, 他: 㐘肉出血を初発症状と した急性前骨髄球性白血病の 1 例。 日口診誌 20 : 179-183 2007.

11) Luc, L.M.W., Luci, B.T.H., et al.: Oral manifestations of leukemia. Ear Nose Throat J 69: 341-346 1990.

12) Tazaki, M., Matsuzaka, K., et al.: Leukemia case in patient with taste dysfunction: case report. Bull Tokyo Dent Coll 46: 33-36 2005.

13）小嶋 瑞：腫瘤形成性白血病. 日血会誌 26: 62-68 1962.

14）平野吉雄, 樋口良三, 他：口腔腫瘤を初発症状とし て発現したと思われる急性骨髄性白血病の 1 例. 日 口外誌 30: 1854-1858 1984.

15）辻 竜雄, 早津良和, 他：菌肉に発生した腫瘤形成 性白血病の 1例. 日口外誌 37: 1490-1491 1991.

16）小森康雄：特異的な口腔壊死を呈した小児急性白血 病の 1 症例. 日口外誌 26: 835-843 1980.

17) Bressman, E., Decter, J.A., et al.: Acute myeloblastic leukemia with oral manifestations. Report of a case. Oral Surg Oral Med Oral Pathol 54: 401-403 1982. 